\title{
On Application of Task-based Approach to Business English Correspondence Teaching
}

\author{
Zhen Zhang \\ School of Economy and Management, \\ Wuhan Polytechnic University \\ Wuhan, China. \\ E-mail: 821304849@qq.com
}

\begin{abstract}
Classroom teaching is the main teaching method in the process of college talent training while the teaching method's reform occupy a vital place in teaching reform. Classroom teaching, as the intrinsic resource to improve teaching quality, is also one of the important factors to achieve the teaching goals. This paper explores the application of TaskBased Language Teaching,, designing appropriate and efficient writing tasks as the core, based on the characteristics of Business English Correspondence Course. The teaching methods of how to arouse students attention an how to enhance student's thinking or practice ability are discussed as well.
\end{abstract}

Keywords-task-based approach; business English correspondence; teaching

\section{INTRODUCTION}

Language training in Business English Correspondence includes both understanding training and expression training. In the past teaching, because of only paying attention to reading teaching and analysis of formats of Business English Correspondence, emphasizing the comprehension reading,, thus lead to the phenomenon of low ability in using language for a part of students. Business English Correspondence Course, actually, is a practice course and its chief goal focuses on training students' practice competence of business letter writing, developing students to be senior compound talents whom are familiar with international business and English language. The author made some attempt on how to reform teaching methods in Business English Correspondence Course in view of the teaching experiences in recent years.

\section{THE APPICATION OF TASK-BASED APPROACH IN BUSINES ENGLISH CORRESPONDENCE COURSE TEACHNNG}

Task-based approach, namely, task-based language teaching. The teaching notion can be traced back to 1980s, which is well approved and accepted by linguists and foreign language teaching practice. The so-called task is the activity which refers to learners' cognition and communicative process, exploring the known and new information by the form of collective, solving some problems which are expectant, temporary and distinguishable in the social language situation. The famous educationist Skechen summarized several main characteristics of task-based approach listed below:

1. For the purpose, it should have actual meaning rather than practice meaningless language form.
2. There is a communicative problem needed to solve, and the problem must have a specific link with the real world, close to the students' life involving working experience and social practice.

3. The design of learning tasks and implementation should focus on completion of the task, namely the solving of some communicative problems, the completion result of the task is a mark to assess whether the results are successful. At the same time, it provides learners with self-assessment standards; the success of solving communicative problems tends to make them have a sense of achievements so as to stimulate their interest in learning.

In Business English Correspondence course teaching, the task-based teaching model requires learner to apply standard and fluent English into completing an actual international business activity. Firstly, design real and specific tasks related to foreign trade procedure, and then present students in class all the steps to international trade practice, students, therefore, can get to the business language in self-learning, also improve their crosscultural communicative competence as well as the handling ability in foreign trade practice.

\section{PRACTICAL EXPERIENCE OF TASK-BASED APPROACH}

Take-based approach emphasizes students' central position in the process of teachting., focuses on ability training, advocates the sociality and contextualized study. Through completion of tasks one by one, students can imrove their expression ability and the strain ability to deal with the actual problems under various business situations. Business English Course require students to particapate in all the activities relating to international trade. The course itself requirement happens to coincide with that of task-based approach teaching. Some experience can be summerized as follows:

\section{A. Reading the Prototype by offering Guidance to Imitation}

Psychology says, the wearing and the form of people's imagination and creativity usually depend on external stimulus or prototype inspiration. Accordingly, in the teaching process, the teachers may analyze and summarize the writing features and technique one by one from those classic models in Business English Correspondence 
Textbook, guide students to read the original text, let them taste the exquisite words, comprehend writing skill, then to determine the imitation content. For example, when lecturing on establishing business relations, First, help students understand the importance of establishing business relations with other companies, and then to analyze the relative specimen letters, let the students observe which sentences are clearly to express writer's desires of building up business relation with receivers, which sentences really arouse the receiver's attention to writer's business scope, and which sentences properly show the receiver's politely reply. By such a careful analysis, all the students can gradually grasp the writing essentials in this chapter, on the basis of understanding the model essay. Before the end of class, the teacher can divide students into Chinese part and foreign part, which are two groups as sender's group and receiver's group, ask them to complete the writing a letter or reply to the letter for establishing business relations. In this way, class teaching trains the students' observation, open their mind, meanwhile improves their expression ability.

\section{B. Penetrating into Sales Promotion by motivating students's potential}

A task-based approach is an activity which request learner to arrive at an outcome from given information through some process of thought, and which allowed teachers to control and regulate that process. Hence, in the teaching of the Chapter "Sales Promotion" of Business English Course, teachers should let students fully understand how to promote and its writing principles, especially the principles of AIDA (Attention, Interest, Desire and Action.) Bring students into international famous enterprises websites which well illustrated the products. All the advertisements for the famous brands, such as Dove chocolate, MercedesBenz automobile, and Gree Central Air condition just give students a sense of how to arouse customer's attention, stimulate their interest, create the desire and urge them to make a quick purchase decision. Just at the moment, let students share their feeling about the charm of vivid words or expressions in the sales letters involving the way to create suspense; the way to describe the products and services. Under the circumstance, slide presentation on Sales letters including Follow-up letters in the class teaching can be adopted. More chances are given by students practice can use business language in a creative situation. In class or after class they may have a group job to promote by writing a sale letter with a quite different product subject. Of course, each student in the class could be a syndic and take an active part in complement or improve the sales letter presented by classmates. In this way, the students are deeply attracted and their writing enthusiasms are greatly mobilized.

\section{Leading students to Rewrite by sticking to writing principles}

On the whole, Business letters writing should adhere to the 7Cs principles, namely Courtesy, Consideration, Completeness, Concreteness, Conciseness, Clarity, and Correctness. The 7Cs principles are properly used in every procedure of international trade covering establishment of business relations, inquiry, offer, counter-offer, acceptance, insurance, packing, transportation, complaint, claim and so on. In chapter of Complaint and Claim, teacher could let students be aware that something undesirable happens sometimes in the process of a deal. For instance, the importers often complain about the damage to the cargo or the delay in shipment, etc. And the exporters complain about the importers failing to perform contracts, or delay in issuing a letter of credit, etc. If the writers cannot state the fact objectively and restrictedly to the other party or can't specify the reason why to complain about, but just writing with aggressive tone, which is harmful to the precious business relations between the importer and the exporter. The teachers, before the lecture, may ask students to read some business letters with inappropriate wording, such as "To our surprise, the goods you delivered are not the same we ordered. We cannot bear your action. It's totally cheating." The statements, according to 7Cs principles, seem clearly but not polite, failed to conform to the requirement of "Courtesy. For this kind of letter, the writers tend to state the unpleasant fact directly and objectively, learn to separate the people from things. In accordance with 7Cs principles, teachers may ask students to rewrite the letter with poor quality and comment on students' modification of the previous letter. After comparison, students are happy to be adjudicator and rewrite actively.

\section{Extending students reading range by offering guideance to the Sketch}

Business English Correspondence Course involves international finance, international law, and other multidisciplinary knowledge. Business letter writing requires being familiar with the related fields and being able to choose proper words to express accurately and concisely. Any delay in response to other side's letter or any reply containing ambiguous words or sentences are likely to result in incalculable economic loss in foreign trade or the collapse of the foreign business relations. Consequently, if the students who major in international business and want to be qualified clerks, they should have the ability to deal with foreign trade practice rather than the exam skill applying into Business English Correspondence Writing. To the purpose, it needs to extend students reading range relating to international business. Furthermore, quick complete the task of writing all kinds of business letter is particularly important. Teachers may arrange some reading task and require students to finish their business letter writing in 15 minutes in class, the scores can be a part of usual performance. Of course, teachers can have a random check and evaluation on the spot. The stressful sketch strengthens student's quick writing competence.

Task-based approach teaching relies both on the learner's ability to learn analytically is necessary in completing tasks focused on meaning rather than grammatical form, the teacher flexibility and creativity are demanded as she / he diagnoses the outcomes of each task 
and create new materials in response to newly revealed learner needs.

\section{CONCLUSION}

Compared with the traditional form-based methodology, the advantages of Task-based approach teaching can be concluded below:

1. Task-based approach teaching offers the opportunity for "natural" learning inside the classroom;

2. It emphasizes meaning over form but can also take account of learning form;

3. It makes the classroom close to foreign trade practice situation;

4. It is intrinsically motivating;

5. It is compatible with a learner centered educational philosophy.

No matter what kinds of teaching approach we adopted, the ultimate goal for teaching is aiming at stimulating students 'interest effectively, inspire students ability of self- learning. Keep them always stay in a positive state of "problemthinking-exploring-solving”. With recent year’s increasing enrollment Business English Correspondence Course Teaching will meet great challengers. Only constant discussion can give the course vitality.

\section{REFERENCES}

[1] Foster, P\&P. Skehan. The influence of planning an task type in second language performance, $[\mathrm{J}]$ Studies in Second Language Acquisition 18, 1996, pp. 299-324

[2] Skehan, P. A cognitive Approach to Language Learning [M] Oxford University Press, 1998, pp.95 [3]Long, M. H\&G, Crookers. Three approaches to task - basked syllabus design. TESOL Quartely26, 1991, pp. 27-56

[3] Zhang Li. The Exploration of Listening and Speaking of Business English Teaching in Higher Vocational College, [J], Scientific \& Technology Information (34) 2007. pp. 159-161

[4] Mark Eiiis Christine Johnson. Teaching Business English [M] Shanghai Foreign Language Education Press, 2002, pp.39

[5] Wu Yunzhu. The Exploration of Compound Talent Training Pattern in local universities [J] Education and occupation, 2009, pp. 48-49

[6] G. Eason, B. Noble, and I. N. Sneddon, "On certain integrals of Lipschitz-Hankel type involving products of Bessel functions,” Phil. Trans. Roy. Soc. London, vol. A247, pp..29-551, 